\title{
ASSESSMENT OF RISK AND UNCERTAINTY FACTORS INHERENT IN NIGERIAN HIGHWAY PROJECT USING ANALYTICAL HIERARCHICAL PROCESS
}

\author{
Oluyemi-Ayibiowu Bamitale Dorcas ${ }^{1}$, Adebote Adewale Paul ${ }^{2}$ \\ and Falola Kayode Emmanuel ${ }^{3}$
}

${ }^{1}$ Department of Civil Engineering, School of Engineering and Engineering Technology, The Federal University of Technology, Akure, Nigeria. E-mail: bayibiowu@yahoo.com

${ }^{2}$ Department of Civil Engineering, School of Engineering and Engineering Technology, The Federal University of Technology, Akure, Nigeria. E-mail: dwldbt@gmail.com

${ }^{3}$ Department of Civil Engineering, School of Engineering and Engineering Technology, The Federal University of Technology, Akure, Nigeria. E-mail: faloular@gmail.com

Cite this article:

Oluyemi-Ayibiowu B.D., Adebote A.P., Falola K.E. (2022), Assessment of Risk and Uncertainty Factors Inherent in Nigerian Highway Project Using Analytical Hierarchical Process. International Journal of Mechanical and Civil Engineering 4(1), 34-51. DOI: 10.52589/IJMCE-

NXNTRNDO

\section{Manuscript History}

Received: 16 Nov 2021

Accepted: 5 Nov 2021

Published: 6 Jan 2022

Copyright $\odot 2020$ The Author(s). This is an Open Access article distributed under the terms of Creative Commons AttributionNonCommercial-NoDerivatives 4.0 International (CC BY-NC-ND 4.0), which permits anyone to share, use, reproduce and redistribute in any medium, provided the original author and source are credited.

\begin{abstract}
The study presents a framework through which risk and uncertainties in Nigeria highway projects can be appraised using the analytical hierarchical process model. Pairwise comparison matrix was performed on eleven (11) risk and uncertainty factors that affect highway project performance through a questionnaire survey conducted among two hundred and four (204) respondents, which involved various stakeholders in the highway construction industry using Saaty's AHP rating scale. The relative weights (significance/impact level) of each of the highway risk factors were estimated during the AHP model development. The results in descending order of risk factors priorities are Standard \& Regulations $(S \& R)$, Construction $(C)$, Project Staff (PS), Project Sponsor (PSp), Design $(D)$, Project Finance $(P F)$, Economic $(E)$, Equipment $(E Q)$, Environmental \& Geotechnical (En\&G), Site Location (SL) and Subcontractor $(S)$ with impact levels of $16.6 \%, 14.2 \%, 13.9 \%, 13 \%$, $12.7 \%, 12.2 \%, 10.8 \%, 9.8 \%, 6.2 \%, 4.2 \%$, and $3.8 \%$ respectively. The model was validated using the statistical consistency test, with the model showing a consistency ratio equal to 0.1. The model was then applied to five (5) highway construction projects which had been constructed to predict the ones with the most and least risks. The result was in tandem with that which was given by the project managers from experiences on the project. This study showed that the Analytical Hierarchical Process (AHP) decision support model can effectively be used for risk assessment and prioritization of highway construction projects for efficient resource utilization in Nigeria.
\end{abstract}

KEYWORDS: Analytical Hierarchical Process, Risk Assessment, Highway Construction, Factors. 


\section{INTRODUCTION}

A risk is defined as the likelihood of an event occurring and its implications for project goals. A positive outcome presents an opportunity, whereas a negative outcome presents a risk (PMI, 2000). To keep the project's cost in check, maintain construction quality, and ensure that project dues are met, risk assessment entails identifying the specific risk, classifying the risk as well as risk analysis and appraisal (ISO, 2009). Highway construction entails a great deal of risk and uncertainty (Nassar et al., 2014). These dangers arise as a result of the engagement of multiple persons/professionals in the construction process, posing a serious threat to the construction pace and quality. To enhance the performance of highway projects, there is a need to identify, assess and schedule various factors of risk in the project for efficient fulfilment of the project (Nagalla, 2018).

\section{LITERATURE/THEORETICAL UNDERPINNING}

Every year, a significant portion of Nigeria's revenue is spent on transportation with its ancillary problems (Akintoye et al., 1997). There are around 4000 unfinished or abandoned projects belonging to the Federal Government of Nigeria, with an estimated cost of over 300 billion naira and a completion time of 30 years based on the government's current execution capacity. This issue of abandonment has gone unaddressed for far too long, and it is now having a multiplier effect on the construction industry in particular, as well as the national economy in general (Akadiri et al., 2013). This is partly due to the high-risk exposure that comes with highway construction projects. Highway projects are riskier than other types of construction because they require large capital investments and complex site circumstances. These dangers cannot be eradicated, but they can be reduced. Formal risk analysis and management approaches, on the other hand, are rarely applied due to a lack of expertise and questions about their fit for construction sector activities. In addition, despite its obvious consequences, the lack of any integrated framework for controlling project risks at each step of highway construction projects for Nigerian highway project managers is a serious cause for concern (Akadiri et al., 2013).

The process of identifying the optimal alternative among all potential options is classified as decision-making; however, attaining an optimized result can be difficult because decisionmakers are frequently challenged with diverse decision-making challenges. Multi-criteria decision making (MCDM) is one of the most significant fields of decision theory and it is used to find the optimum answer out of a large number of options (Ishizakar \& Labib, 2011; Hsueh et al., 2007). Several strategies have been developed to help with MCDM improvements, some of which are Analytic hierarchy process (AHP) (Saaty, 2005); superiority and inferiority ranking technique (Yu et al., 2011); Simos' ranking method (Wang et al. 2003); multi-attribute utility theory (MAUT) (Chan et al. 2001); elimination and choice corresponding to reality (ELECTRE) (Ruiz et al., 2012); preference ranking organization method for enrichment evaluations (PROMETHEE) and choosing by advantages (CBA). 
The Analytical Hierarchy Process (AHP) is a mathematical and psychological method for organizing and analyzing complex decisions. It's a decision-making strategy for complicated contexts in which many variables or criteria are taken into account while prioritizing and selecting alternatives or initiatives. AHP is commonly utilized in multi-criteria decision making in real-world situations to solve multi-attribute decision making problems. It is an effective strategy for resolving complex and unstructured situations with several aims and goals that may have interactions and correlations. The AHP helps the decision makers to organize the critical aspects of a problem into a hierarchical structure similar to a family tree (Damjan Maletič et al., 2016).

AHP is a well-known MCDM method that has been in use over the last two decades in the construction industry as a construction decision making tool. It enables decision-makers to analyze probable alternatives using many criteria in a quantitative manner and then choose the best option.

\section{Previous Reviews on Use of Value Engineering Technique}

Khazandi et al. (2012) used FSs-AHP (Fuzzy set Analytic Hierarchical Process) together with the Delphi method to resolve the problem of unbalanced allocation of risks among contracting parties. Specifically, the fuzzy adaptive decision-making model presented was used to select the most appropriate allocation of risks among contracting parties.

Hsueh et al. (2007) applied a combination of AHP and utility theory (UT) to develop a multicriteria risk assessment model for contractors to reduce risks in joint ventures. AHP was first used to weight a set of risk criteria. Utility functions were then used to convert risks into numerical rates for ascertaining the expected utility values of various scenarios.

Ali and Al Nsairat (2009) used AHP to develop a green building rating tool. After identifying the green building assessment criteria, the criteria were weighted and prioritized using AHP. Similarly, Lai and Yik (2009) applied AHP to identify the significant indoor environmental quality areas in high-rise residential buildings. Lai and Yik (2009) claimed that AHP can assist facility managers in managing buildings within constrained budgets.

\section{METHODOLOGY}

\section{Study Areas}

The study area selected for this research is Lagos State, Nigeria. This choice was based on the fact that the state holds a proportionate large volume of construction activities in the country and its economic viability. 
Lagos State lies in the South-western part of the Federation. It lies between latitude of $6^{\circ} 27^{\prime} 14.65^{\prime \prime} \mathrm{N}$ and longitude of $3^{\circ} 23^{\prime} 40.81^{\prime}$ 'E. It shares boundaries with Ogun State both in the North and East and is bounded on the West by the Republic of Benin. In the South, it stretches for $180 \mathrm{~km}$ along the coast of the Atlantic Ocean. It occupies an area of 3,577 sq. km., $22 \%$ of which consists of lagoons and creeks and with an estimated population of 9,019,534. Lagos is a center of business opportunities in diverse industries like consulting, manufacturing, construction, oil and gas, agriculture, telecom, marketing, legal, health, etc.

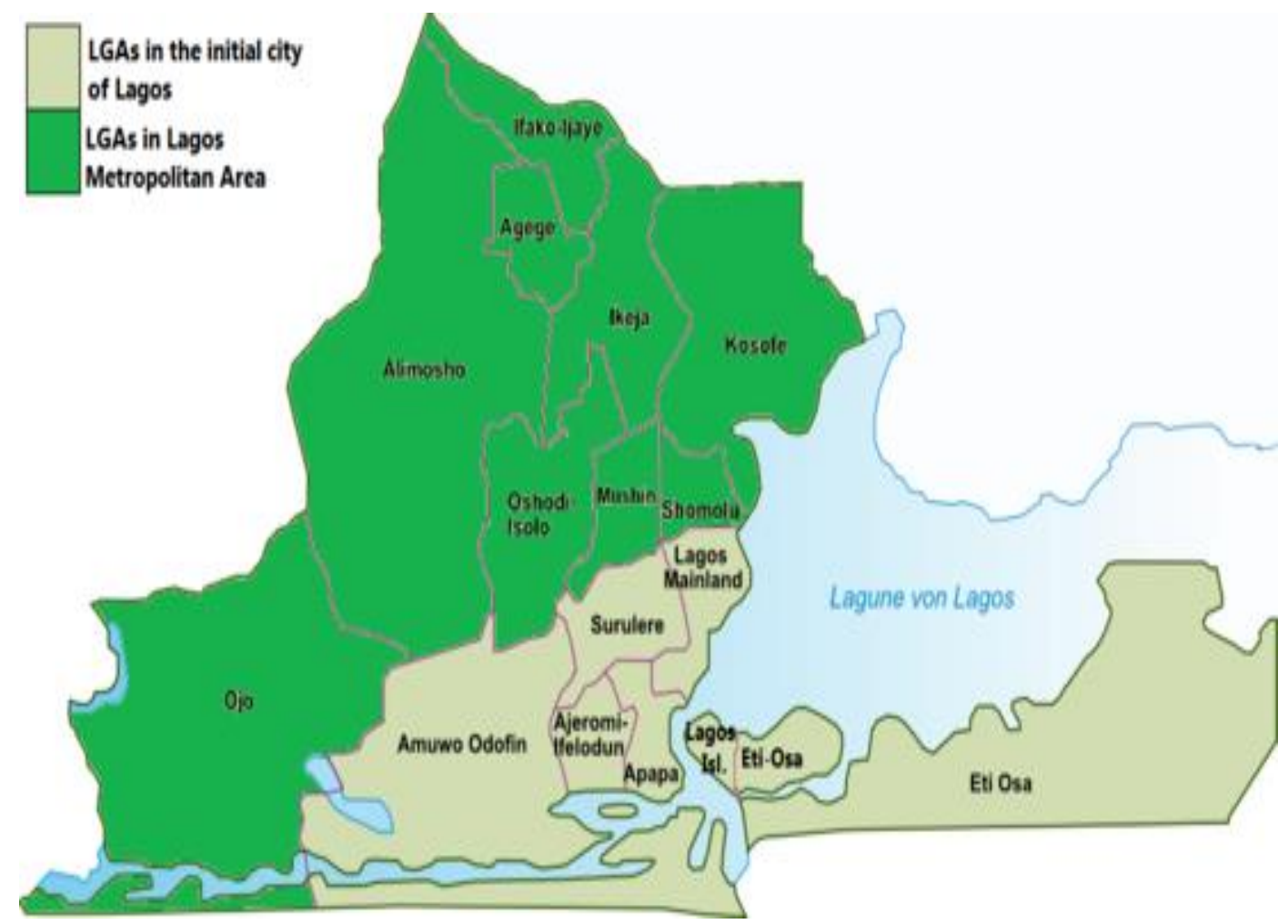

Figure 1: Map of the Study Area (Lagos)

\section{Design of Questionnaire}

The questionnaire was designed to get necessary information from highway construction professionals and other administrative personnel. Survey will be carried out through literature reviews and structured interview on lists of risks and uncertainties as regards highway construction projects. The research questionnaire will be however structured for pairwise comparison among the list of risks and uncertainty factors in terms of their importance and consequences of occurrence. This pairwise comparison among risk factors is very vital in the development of the AHP model and it will be done by experts at all levels of highway construction. The flow chart for the questionnaire research and development is shown in figure 2. 


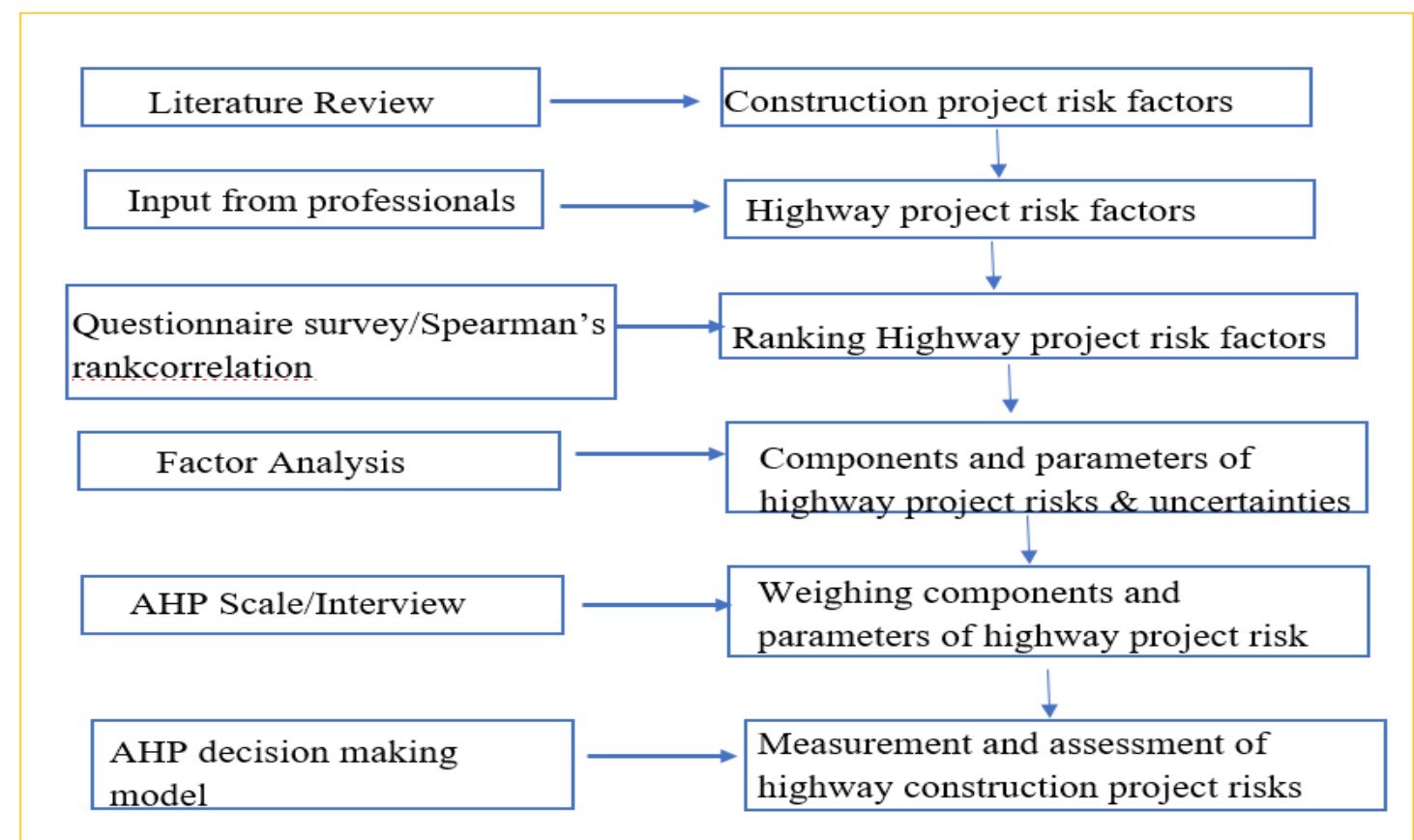

Figure 2: The Research Framework/ Flowchart

\section{AHP Model Development}

The AHP decision support system (DSS) model will be performed in four major steps. The first step is to create a hierarchy of the problem. The second step is to give a nominal value to each level of the hierarchy and create a matrix of pairwise comparison judgement. The third step is the normalization of the pairwise comparison matrix and lastly, the fourth step is the estimation of the relative weights of the major elements in the hierarchy structure.

\section{Highway Project Risk Hierarchial Structure}

The first and major step is the development of a tree-like hierarchial structure of the problem. The first level of the hierarchy structure would represent the decision goal which in this case is the Highway Project risks. The second lower levels of the hierarchy structure contain the progressive breakdown of the decision goals into decision variables/criteria. However, after extensive literature reviews and responses from highway project expert judgement, the following major highway project risk factors were gathered and represented in the next level of the hierarchy structure development. These factors were: economical, project finance, standards and regulations, project sponsors, design, subcontractors, equipment, site location, project staff, environmental and geotechnical, construction. The subsequent lower levels represented the breakdown of the decision variables/criteria into sub-criteria showing the various categories of events under each highway risk factor. The developed hierarchy problem structure for highway risk assessment in Nigeria goes thus: 


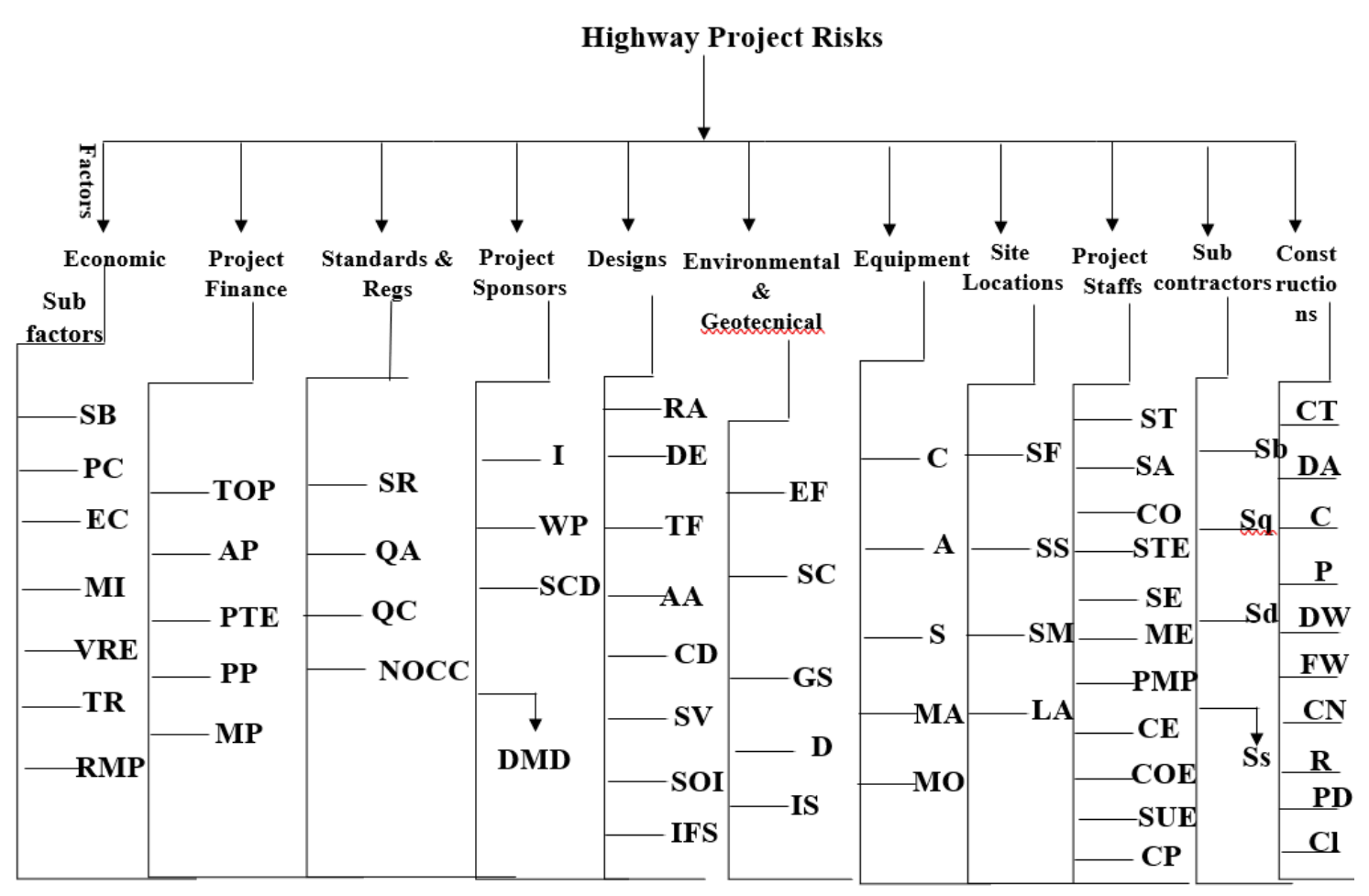

Figure 3: Highway Project Risk Hierarchial Structure

where

$\begin{array}{llll}\text { Economic: } & \text { SB is } & \text { Sponsor Bankrupt } \\ & \text { PC is } & \text { Political Changes } \\ \text { EC is } & \text { Economic Crisis } \\ \text { MI is } & \text { Market Inflation } \\ \text { VRE is } & \text { Variable Rate of Exchange } \\ \text { TR is } & \text { Taxation Risk } \\ \text { RMP is } & \text { Raw Materials Prices } \\ \text { Project Finance: } & \text { TOP is } & \text { Time of Payments } \\ & \text { AP is } & \text { Advanced Payment } \\ & \text { PTE is } & \text { Project Time Extension } \\ & \text { PP is } & \text { Procurement Plan } \\ \text { MP is } & \text { Material Procurement }\end{array}$

Standards and Regulations: SR is Safety Regulations

QA is Quality Assurance

QC is Quality Control

NOCC is Not Applying Cost Control 


$\begin{array}{llll}\text { Project Sponsors: } & \text { I } & \text { is } & \text { Interference } \\ & \text { WP is } & \text { Work Permits } \\ \text { SCD is } & \text { Short Contract Duration } \\ \text { DIMD is } & \text { Delay in Making Decisions }\end{array}$

Equipment:

$\begin{array}{lll}\text { C } & \text { is } & \text { Condition } \\ \text { A } & \text { is } & \text { Availability } \\ \text { S } & \text { is } & \text { Storage } \\ \text { MA } & \text { is } & \text { Maintenance } \\ \text { MO } & \text { is } & \text { Mobilization }\end{array}$

$\begin{array}{llll}\text { Site Locations: } & \text { SF } & \text { is } & \text { Site Facilities } \\ & \text { SS } & \text { is } & \text { Site Security } \\ & \text { SM } & \text { is } & \text { Site Mobilization } \\ & \text { LA } & \text { is } & \text { Land Acquisition }\end{array}$

\begin{tabular}{|c|c|c|c|}
\hline \multirow[t]{11}{*}{ Project Staffs: } & ST & is & Staff Training \\
\hline & SA & is & Staff Availability \\
\hline & $\mathrm{CO}$ & is & Change in Organization \\
\hline & STE & is & Staff Teamwork \\
\hline & SE & is & Staff Experience \\
\hline & ME & is & Manager Experience \\
\hline & PMP & is & Project Management Plan \\
\hline & $\mathrm{CE}$ & is & Consultant Experience \\
\hline & $\mathrm{COE}$ & is & Contractor Experience \\
\hline & SUE & is & Subcontractor Experience \\
\hline & $\mathrm{CP}$ & is & Communication Plan \\
\hline \multirow[t]{4}{*}{ Subcontractors: } & $\mathrm{Sb}$ & is & Subcontractor Bankruptcy \\
\hline & $\mathrm{Sq}$ & is & Subcontractor Quality \\
\hline & $\mathrm{Sd}$ & is & Subcontractor Delay \\
\hline & Ss & is & Subcontractors \\
\hline
\end{tabular}


International Journal of Mechanical and Civil Engineering

ISSN: 2689-940X

Volume 4, Issue 1, 2021 (pp. 34-33)

www.abjournals.org

$\begin{array}{llll}\text { Constructions: } & \text { CT } & \text { is } & \text { Contract Terms } \\ & \text { DA } & \text { is } & \text { Delay in Approval } \\ \text { C } & \text { is } & \text { Conflicts } \\ & \text { P } & \text { is } & \text { Productivity } \\ \text { DW } & \text { is } & \text { Defective Work } \\ \text { FW } & \text { is } & \text { Failure of Work } \\ & \mathrm{CN} & \text { is } & \text { Changing Need } \\ \text { R } & \text { is } & \text { Rework } \\ & \text { PD } & \text { is } & \text { Project Delay } \\ & \mathrm{C} & \text { is } & \text { Claims }\end{array}$

\section{Highway Project Risks Pairwise Comparison Matrix Development}

A pairwise comparison among each highway risk factor at the top level was conducted in a structured manner leading to the formation of a Pairwise Comparison Matrix table as shown in table 2 .

Table 2: Highway Project Risk Pairwise Comparison Matrix

\begin{tabular}{|l|l|l|l|l|l|l|l|l|l|l|l|}
\hline EC & EC & PF & S\&R & PS & D & En\&G & EQ & SL & PS & S & C \\
\hline PF & & & & & & & & & & & \\
\hline S\&R & & & & & & & & & & & \\
\hline PS & & & & & & & & & & \\
\hline D & & & & & & & & & & \\
\hline En\&G & & & & & & & & & & \\
\hline EQ & & & & & & & & & & & \\
\hline SL & & & & & & & & & & & \\
\hline PSp & & & & & & & & & & & \\
\hline S & & & & & & & & & & & \\
\hline C & & & & & & & & & & & \\
\hline
\end{tabular}

where

EC is Economic

$\mathrm{PF}$ is Project Finance

S\&R is Standards \& Regulations

$\mathrm{D}$ is Design

En\&G is Environmental \& Geotechnical

$\mathrm{EQ}$ is Equipment

SL is Site Locations 


$\begin{array}{lll}\text { PS } & \text { is } & \text { Project Staff } \\ \text { S } & \text { is } & \text { Subcontractors } \\ \text { C } & \text { is } & \text { Construction } \\ \text { PSp } & \text { is } & \text { Project Sponsors }\end{array}$

To perform these comparisons, an experimental survey was conducted among randomly selected two hundred and four highway project professionals consisting of clients, project managers, consultants and contractors to evaluate the importance of each risk factor against one another. The question the respondents were asked goes thus: "If given only the resources to mitigate against one of these two highway risk factors, taking into consideration all the risk sub factors under each risk, rate how important your preference of one to the other is based on their level of impact?" The rating was performed based on Saaty's scale of measurement in pairwise comparison. Table 3 showed the highway project risk pairwise comparison measurement scale.

Table 3: Saaty's Scale of Pairwise Comparison Measurement

\begin{tabular}{|l|l|l|}
\hline Intensity of Importance & Definition & Explanation \\
\hline 1 & Equal Importance & Two factors contributing equally \\
\hline 3 & Moderate Importance & $\begin{array}{l}\text { Experience and judgement slightly } \\
\text { favor one over another }\end{array}$ \\
\hline 5 & Strong Importance & $\begin{array}{l}\text { Experience and judgement } \\
\text { strongly favor one over another }\end{array}$ \\
\hline 9 & Very Strong Importance & $\begin{array}{l}\text { A risk is strongly favored and its } \\
\text { dominance is demonstrated in } \\
\text { practice }\end{array}$ \\
\hline $2,4,6,8$ & Absolute Importance & $\begin{array}{l}\text { The importance of one over is } \\
\text { affirmed on the highest possible } \\
\text { order }\end{array}$ \\
\hline
\end{tabular}

If a risk $i$ has a particular number assigned to it when compared with a risk $j$, then risk $j$ would have the reciprocal value when compared with risk $i$. For example, if economic risk has a comparison value of 3 when compared with equipment risk, then equipment risk would have a comparison value of $1 / 3$ or 0.333 when compared with economic risk.

\section{Estimation of the Relative Weights of the Highway Risk Factor Elements}

The relative weight of each risk factor element is a mathematical representation of the importance and impact of each risk element in the pairwise comparison matrix. It shows its ranking and impact if it occurs in a highway construction project in a mathematical format. The estimation of the relative weights of the risk factor elements was done by taking the row average of each element normalized pairwise comparison result. The row average is the average along the rows of each risk element calculated as the sum of the normalized pairwise 
result of each element along the rows of the element divided by the total number of risk factor elements. This was done for all the risk factor elements and their result was stored under a column table with the column heading of relative weights. The calculations were done using the mathematical functions of the Microsoft Excel 2019 edition.

\section{Validation of the AHP Decision Model}

\section{The Consistency Ratio Test}

The consistency ratio is an important measure of consistency for pairwise comparisons of the experts' judgements. Consistency ratio (CR) is determined from equation 1 and 2:

Consistency ratio $=\mathrm{CR}=\frac{C I}{R C}$

Consistency index $=\mathrm{CI}=\frac{\lambda_{\max }-n}{n-1}$ (2) (Lee, 2007)

where $\mathrm{CI}=$ consistency index; $\mathrm{n}=$ size of matrices; $\lambda_{\max }=\max (\mathrm{n}) ; \mathrm{RI}=$ random index.

Saaty (1980) proposed the random index RI based on the size of matrices $\mathrm{n}$. CR should not be more than $10 \%$ or 0.1 (Saaty, 1980). If CR is greater than $10 \%$, the inconsistency in comparisons in the decision-making matrix is unacceptable. In that case, as suggested by Saaty (2005), we can identify which judgement is the most inconsistent and determine a range of values that can be varied to increase consistency. Finally, the respective experts will be contacted again to review their comparisons (Saaty, 2005). If the resulting CR is still too large, the judgement will be excluded.

\section{Application to Highway Construction Projects Prioritization}

The risk assessment score of a project is the sum total of the result of the product of the impact and probability of all risks involved with/correlated to the project. To verify the effectiveness of the developed AHP decision model, a reputable construction company, with over 30 years of highway project construction in Nigeria, was used. Pairwise comparison matrix data were collected for five (5) highway construction projects under each of the risk elements involved in the AHP model development.

The company was asked these questions "Comparing these two projects with the resource level at the time of undertaking of the projects, rate the level at which the following risk factor and its associated scenarios/impact significantly occur/influence the project outcome?" The companies were then asked to state the least risky project and the most risky project. From the responses gathered, P1 was the least risky project while P4 was the most risky one. The AHP decision model however is expected to predict these outcomes from the pairwise comparison matrix information extracted. 


\section{RESULTS/DISCUSSION}

\section{Questionnaire Distribution and Responses}

A total of two hundred and four (204) questionnaires were distributed to randomly selected respondents (contractors, consultants, project managers and clients) in the study area which was Lagos. A total of one hundred and ninety (190) responses were collected, evaluated and analyzed, which represented $93.13 \%$ respondent rate for the research. The respondents consisted of contractors, consultants, project managers and clients with wealth of experiences in highway project execution in Nigeria. Table 4 showed the volume of each of the categories of respondents in the questionnaire research survey conducted.

Table 4: Categories of Respondents

\begin{tabular}{lll}
\hline CATEGORIES & QUANTITY & QUANTITY IN \% \\
\hline Contractor & 45 & $23.7 \%$ \\
Consultant & 69 & $36.3 \%$ \\
Project Manager & 56 & $29.5 \%$ \\
Client & 20 & $10.5 \%$ \\
Total & 190 & $100.0 \%$ \\
\hline
\end{tabular}

Contractor respondent category consisted of forty-five (45) respondents which represented $23.7 \%$ of the total number of respondents, consultant respondent category had sixty-nine (69) respondents which represented $36.3 \%$ of the total number of respondents, project manager category had fifty-six (56) respondents which represented $29.5 \%$ of the total number of respondents, while the client category makeup contained twenty (20) respondents which represented $10.5 \%$ which is the least of the total number of respondents used for the research. Figure 4 shows the respondents' categories and their frequency, while figure 5 shows their percentage representation on a pie chart.

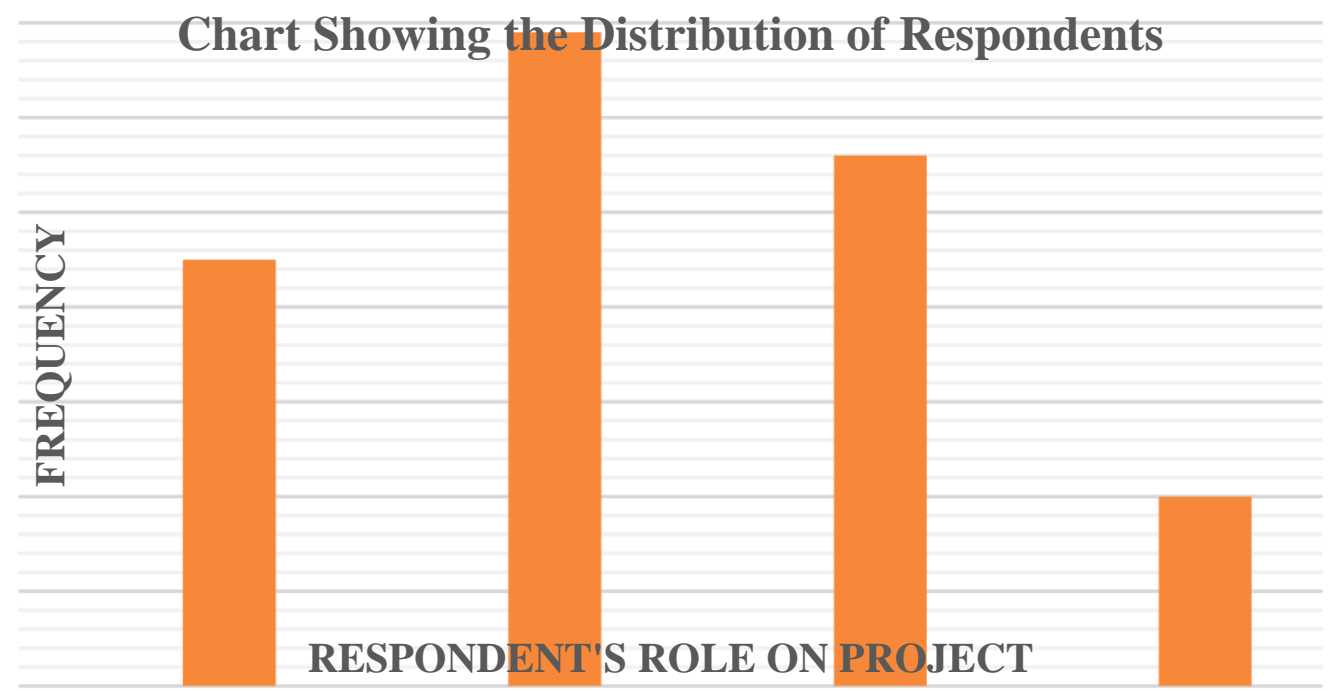

Figure 4: Frequency Distribution of Respondents 


\section{Pie Chart showing \% Respondents Distribution}

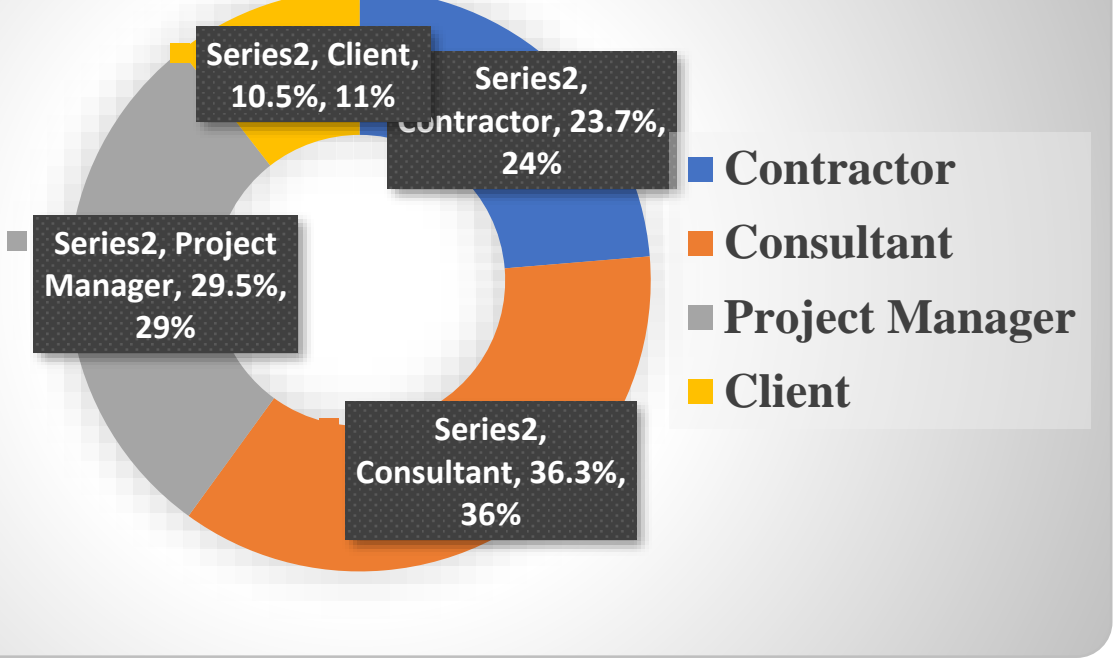

Figure 5: Percentage Distribution of Respondents

\section{Highway Project Risk Factors Pairwise Matrix}

Table 5 below showed the highway project risk factors pairwise comparison matrix, which is a result of the statistical survey conducted in which each of the risk factors were compared with one another using a rating scale as stipulated in table 3 . The maximum rating score from the pool of ratings from the one hundred and ninety (190) respondents for each two compared factors was used as the final and inputted rating score. The result was displayed in a matrix format called pairwise comparison matrix. If a risk $i$ has a particular number assigned to it when compared with a risk $j$, then risk $j$ would have the reciprocal value when compared with risk $i$. Also, for two like risk factors, a unit value of 1 is assigned to it in the matrix.

Table 5: Highway Project Risk Factors Pairwise Comparison Matrix

\begin{tabular}{|l|l|l|l|l|l|l|l|l|l|l|l|}
\hline & EC & PF & S\&R & PS & D & En\&G & EQ & SL & PSp & S & C \\
\hline EC & 1 & 2 & $1 / 2$ & $1 / 2$ & 2 & 5 & 3 & 3 & $1 / 3$ & 2 & $1 / 3$ \\
\hline PF & $1 / 2$ & 1 & $1 / 3$ & $1 / 2$ & 2 & 5 & 4 & 2 & $1 / 2$ & 2 & 2 \\
\hline S\&R & 2 & 3 & 1 & $1 / 2$ & $1 / 2$ & 4 & 3 & 4 & 2 & 5 & 3 \\
\hline PS & 2 & 2 & 2 & 1 & $1 / 2$ & 4 & $1 / 2$ & 5 & 2 & 4 & $1 / 2$ \\
\hline D & $1 / 2$ & $1 / 2$ & 2 & 2 & 1 & 3 & 3 & 5 & $1 / 3$ & 4 & $1 / 2$ \\
\hline En\&G & $1 / 5$ & $1 / 5$ & $1 / 3$ & $1 / 4$ & $1 / 3$ & 1 & 3 & 5 & $1 / 3$ & 2 & $1 / 3$ \\
\hline EQ & $1 / 3$ & $1 / 4$ & $1 / 3$ & 2 & $1 / 3$ & $1 / 3$ & 1 & 4 & 5 & 3 & $1 / 3$ \\
\hline SL & $1 / 3$ & $1 / 2$ & $1 / 4$ & $1 / 5$ & $1 / 5$ & $1 / 5$ & $1 / 4$ & 1 & 3 & $1 / 4$ & $1 / 5$ \\
\hline PSp & 3 & 2 & $1 / 2$ & $1 / 2$ & 3 & 3 & $1 / 5$ & $1 / 3$ & 1 & 3 & 2 \\
\hline S & $1 / 2$ & $1 / 2$ & $1 / 5$ & $1 / 4$ & $1 / 4$ & $1 / 2$ & $1 / 3$ & 4 & $1 / 3$ & 1 & $1 / 5$ \\
\hline $\mathbf{C}$ & 3 & $1 / 2$ & $1 / 3$ & 2 & 2 & 3 & 3 & 5 & $1 / 2$ & 5 & 1 \\
\hline
\end{tabular}




\section{Estimation of the Relative Weights of the Highway Risk Factors Elements Result}

Relative weights showed the level of importance of variables/elements to a given objective in a mathematical format usually in percentages. Table 6 showed the relative weights of each of the highway risk factors by taking the average across rows of each of the elements in the $11 \times 11$ matrix. The rows of a matrix are the horizontal arrangement of elements in a matrix while the columns are the vertical arrangement of elements in a matrix.

Table 6: Relative Weights of the Highway Risk Factors Elements

\begin{tabular}{|l|l|l|l|l|l|l|l|l|l|l|l|l|l|}
\hline & EC & PF & S\&R & PS & D & $\begin{array}{l}\text { En\& } \\
\text { G }\end{array}$ & EQ & SL & PSp & S & C & $\begin{array}{l}\text { Weig } \\
\text { hts }\end{array}$ & $\begin{array}{l}\text { Weights } \\
\text { in \% }\end{array}$ \\
\hline EC & 0.075 & 0.161 & 0.164 & 0.052 & 0.165 & 0.172 & 0.141 & 0.078 & 0.023 & 0.125 & 0.032 & 0.108 & 10.8 \\
\hline PF & 0.037 & 0.080 & 0.043 & 0.072 & 0.165 & 0.172 & 0.188 & 0.092 & 0.133 & 0.164 & 0.192 & 0.122 & 12.2 \\
\hline S\&R & 0.150 & 0.241 & 0.128 & 0.152 & 0.161 & 0.138 & 0.131 & 0.154 & 0.125 & 0.160 & 0.288 & 0.166 & 16.6 \\
\hline PS & 0.150 & 0.161 & 0.277 & 0.103 & 0.141 & 0.138 & 0.123 & 0.130 & 0.130 & 0.128 & 0.049 & 0.139 & 13.9 \\
\hline D & 0.037 & 0.040 & 0.257 & 0.206 & 0.083 & 0.103 & 0.141 & 0.130 & 0.122 & 0.128 & 0.148 & 0.127 & 12.7 \\
\hline En\&G & 0.015 & 0.026 & 0.043 & 0.026 & 0.030 & 0.077 & 0.141 & 0.130 & 0.052 & 0.064 & 0.082 & 0.062 & 6.2 \\
\hline EQ & 0.025 & 0.020 & 0.064 & 0.206 & 0.048 & 0.011 & 0.047 & 0.106 & 0.326 & 0.096 & 0.132 & 0.098 & 9.8 \\
\hline SL & 0.025 & 0.040 & 0.032 & 0.041 & 0.017 & 0.007 & 0.052 & 0.026 & 0.196 & 0.008 & 0.019 & 0.042 & 4.2 \\
\hline PSp & 0.224 & 0.161 & 0.064 & 0.052 & 0.258 & 0.103 & 0.009 & 0.009 & 0.265 & 0.096 & 0.192 & 0.130 & 13 \\
\hline S & 0.037 & 0.040 & 0.026 & 0.046 & 0.021 & 0.017 & 0.016 & 0.114 & 0.042 & 0.032 & 0.029 & 0.038 & 3.8 \\
\hline C & 0.424 & 0.040 & 0.043 & 0.206 & 0.185 & 0.103 & 0.141 & 0.130 & 0.033 & 0.160 & 0.096 & 0.142 & 14.2 \\
\hline
\end{tabular}

The values before the weights on the table were derived by normalization of the pairwise comparison matrix. Normalization, as regards data processing, is the process of structuring data in a database, usually a relational database, in accordance with a series of normal forms and steps in order to reduce data redundancy and improve data integrity. It is a vital part of any data processing.

From the table, the most important risk factor element is the S\&R (Standard and Regulations) which is the part of the risk factors that deals with the quality of the highway project. It was closely followed by the construction risk factor element that dealt with the contractual terms, productivity of the staff and work errors and mistakes. This showed the importance of good and working contract terms to the successful execution of highway projects in Nigeria. It also showed the impact of mistakes and errors on the project work as the cost of correction is very high for a highway construction project. This was closely followed by the PS (Project Staff) risk factor. This showed the importance of the quality and experience of the project staff to the successful execution of an highway project as all activities productivity and quality revolves around their level of intelligence, administrative, supervision, coordinating and problem solving skills. This risk factor element was closely followed by the PSp (Project Sponsor). The Project Sponsor played an important role in the effective execution of a Highway project on time. The more stable and coordinated the Project Sponsors are, the less risk involved in execution of the project at due time. Unnecessary interference and delays on their part is a high risk to untimely execution of the project. 
The next important risk factor is the Design risk factor. Flaws in the project due to design would affect the effectiveness of the work during its service periods and also show incompetency on the contractor aspects as a result; errors due to design pose a significant level of risks to an highway construction project. PF (Project Finance) and EC (Economic) risk factors followed closely with PF coming before the EC. These are the monetary and cash flow elements of the project and are also important to the successful execution of the project at due time. The level and consistency of cash flow and good economic conditions that prevent raw materials price fluctuations goes a long way in successful project delivery at the predicted and estimated cost. However negative outcomes from these two risk elements pose a significant danger of the highway project experiencing cost overrun.

The other risk element factors showed minute level of importance and posed a slight level of danger/risk towards successful execution of the project. However, their level of importance followed the following order: Equipment, Environmental and Geotechnical, Site location and subcontractor.

\section{AHP Model Validation Result}

\section{Consistency ratio result}

Table 7 shows the result of the calculation of the weighted sum value, lambda $(\lambda)$ and lambda $\max \left(\lambda_{\max }\right)$ from lambda by calculating the mean of the individual lambda $(\lambda)$ of each risk element factors in the pairwise matrix

Table 7: Estimation of Lambda $(\lambda)$ and Lambda Max $\left(\lambda_{\max }\right)$

\begin{tabular}{|c|c|c|c|c|c|c|c|c|c|c|c|c|c|c|}
\hline & EC & PF & S\&R & PS & D & \begin{tabular}{|l} 
En\& \\
G \\
\end{tabular} & EQ & SL & PSp & $\mathbf{S}$ & C & \begin{tabular}{|l|} 
Weighted \\
Sum \\
Value
\end{tabular} & Weights & $\lambda$ \\
\hline EC & 0.093 & 96 & 0.072 & 0.060 & 0.217 & .250 & 0.256 & 0.110 & 0.037 & 0.061 & 0.041 & 1.393 & 0. & 12.940 \\
\hline PI & 047 & 98 & 0.048 & 0.060 & 7 & 250 & 0.341 & 0.073 & 0.056 & 0.061 & 0.24 & 1.495 & $t$ & 2.252 \\
\hline | & 0.186 & 0.294 & 0.143 & 0.060 & 0.054 & 0.200 & 0.256 & 0.146 & 0.222 & 0.154 & 0.366 & 2.082 & 0.100 & 12.554 \\
\hline PS & 0.186 & 0.196 & 0.286 & 0.119 & 0. & 0.200 & 0.043 & 0.183 & 0.222 & 0.123 & 0.061 & 674 & & 12.061 \\
\hline D & 47 & 19 & 0. & c & 0. & 0.150 & 56 & 183 & 037 & 23 & 0.06 & 39 & & 12.150 \\
\hline En\& & 0.019 & 0.020 & 0.048 & 0 & 0. & 050 & 0.256 & 0.183 & 0.037 & 0.061 & 0.0 & 0.780 & & 12.57 \\
\hline EQ & 0.031 & 0.025 & 0.048 & & & & 0.085 & 0.146 & 0.556 & 0.092 & 0.041 & 15 & & 13.40 \\
\hline SL & 0.031 & 49 & 0.036 & 0 & 0. & 0.010 & 0.021 & 0.037 & 0.334 & 0.008 & 0.024 & 95 & 0 & 14.2 \\
\hline PSp & 0.280 & 0.196 & 0.072 & 0.060 & 0.326 & .150 & 0.017 & 0.012 & 0.111 & 0.092 & 0.244 & 1.560 & 0. & 12.02 \\
\hline $\mathbf{S}$ & 0.047 & 0.049 & 0.029 & 0.030 & 0.027 & 0.025 & 0.028 & 0.146 & 0.037 & 31 & 0.024 & 73 & 0.038 & 12.461 \\
\hline C & 0.280 & 0.049 & 0.048 & 0.238 & 0.217 & 0.150 & 0.256 & 0.183 & 0.056 & 0.154 & 0.122 & 1.752 & 0.142 & 12.361 \\
\hline & & & & ofmax & 12.643 & & & & & & & & & \\
\hline
\end{tabular}


The consistency index (CI) was then calculated using the formula: Consistency index $=\mathrm{CI}=$ $\frac{\lambda_{\max }-n}{n-1}$, where $\mathrm{n}$ is the number of highway risk factor elements in the matrix which stands at eleven (11) and The Consistency ratio was calculated using the formula: Consistency ratio = $\mathrm{CR}=\frac{C I}{R I}$. Where CI is the consistency index cand RI value is derived from the Saaty propose Random Index table as shown in table 3.3

Therefore, Consistency index $=\mathrm{CI}=\frac{12.643-11}{11-1}=\frac{1.643}{10}=0.1643$

$$
\text { Consistency ratio }=\mathrm{CR}=\frac{0.1643}{1.64}=0.100
$$

Since the consistency ratio $=0.1$, then the pairwise comparison matrix is consistent.

\section{Application to Highway Project Prioritization}

Table 8 showed the result of the estimated relative weights of each of the highway risk factors based on their occurrence in five (5) highway construction projects. Each of the construction projects were compared with each other in times of occurrence/influence using a rating scale. The weights of each risk factor were calculated. The weight column represents the weight of each risk factor element from the initial AHP Model development while the project weight for each risk factor is shown under each project column.

Table 8: Project Validation and Risk Factors Weight

\begin{tabular}{|l|l|l|l|l|l|l|}
\hline RISK FACTORS & WEIGHT & P1 & P2 & P3 & P4 & P5 \\
\hline EC & 0.108 & 0.1183 & 0.2278 & 0.0692 & 0.4410 & 0.1437 \\
\hline PF & 0.122 & 0.0406 & 0.2507 & 0.0801 & 0.4568 & 0.1718 \\
\hline S\&R & 0.166 & 0.0359 & 0.2336 & 0.0908 & 0.4806 & 0.1590 \\
\hline PS & 0.139 & 0.0516 & 0.2836 & 0.0948 & 0.3875 & 0.1825 \\
\hline D & 0.127 & 0.0773 & 0.2538 & 0.1416 & 0.4103 & 0.1170 \\
\hline En\&G & 0.062 & 0.7195 & 1.1857 & 1.5561 & 1.0605 & 0.4782 \\
\hline EQ & 0.098 & 0.0735 & 0.2585 & 0.0839 & 0.3347 & 0.2493 \\
\hline SL & 0.042 & 0.2924 & 0.2161 & 0.1141 & 0.1611 & 0.2163 \\
\hline PSp & 0.130 & 0.0469 & 0.2253 & 0.1341 & 0.4640 & 0.1298 \\
\hline S & 0.038 & 0.2508 & 0.2770 & 0.0643 & 0.1830 & 0.2249 \\
\hline C & 0.142 & 0.0410 & 0.2581 & 0.0802 & 0.4531 & 0.1676 \\
\hline
\end{tabular}

Table 9 showed the risk assessment score for each highway construction project. A risk score is a product of the probability of occurrence of a particular risk and its impact if it occurred. This was achieved by multiplication of the weights of each risk factor with the project weights and then summing up the values for each score. 


\begin{tabular}{|l|l|l|l|l|l|}
\hline RISK FACTORS & P1 & P2 & P3 & P4 & P5 \\
\hline EC & 0.0127 & 0.0245 & 0.0074 & 0.0475 & 0.0155 \\
\hline PF & 0.0050 & 0.0306 & 0.0098 & 0.0557 & 0.0210 \\
\hline S\&R & 0.0060 & 0.0388 & 0.0151 & 0.0797 & 0.0264 \\
\hline PS & 0.0072 & 0.0394 & 0.0132 & 0.0538 & 0.0253 \\
\hline D & 0.0098 & 0.0321 & 0.0179 & 0.0520 & 0.0148 \\
\hline En\&G & 0.0446 & 0.0735 & 0.0965 & 0.0658 & 0.0297 \\
\hline EQ & 0.0072 & 0.0254 & 0.0082 & 0.0328 & 0.0244 \\
\hline SL & 0.0122. & 0.0090 & 0.0048 & 0.0067 & 0.0090 \\
\hline PSp & 0.0061 & 0.0292 & 0.0174 & 0.0602 & 0.0168 \\
\hline S & 0.0095 & 0.0105 & 0.0024 & 0.0069 & 0.0085 \\
\hline C & 0.0058 & 0.0366 & 0.0114 & 0.0642 & 0.0238 \\
\hline SUM & 0.1260 & 0.3496 & 0.2041 & 0.5253 & 0.2152 \\
\hline SUM IN \% & $12.60 \%$ & $34.96 \%$ & $20.41 \%$ & $52.53 \%$ & $21.52 \%$ \\
\hline
\end{tabular}

The table shows that the riskiest project is project four (4) with a risk score of $52.53 \%$ while the least risky project is project one (1) with a risk score of $12.60 \%$. This supports the result from the response from the construction company project managers as regards the most risky and the least risky of the highway projects. In terms of how risky the projects are, in ascending order, the results are: Project $1<$ Project $3<$ Project $5<$ Project $2<$ Project 4 .

This showed the effectiveness of the highway risk AHP model in predicting how risky a project is and can be used in highway project prioritization where resources are limited to achieve maximum output and risk mitigation.

\section{CONCLUSIONS}

- The most important highway risk factor element is the S\&R (Standard and Regulations) which is the part of the risk factors that deals with the quality of the highway project.

- The second important highway risk factor element is the construction risk factor element that deals with the contractual terms, productivity of the staff and dealing with work errors and mistakes.

- The third most important highway risk factor element is the PS (Project Staff) risk factor that deals with the level of intelligence, administrative, supervision, coordinating and problem-solving skills of the project staff.

- The fourth most important highway risk factor element is the PSp (Project Sponsor) risk factor that deals with the interference, delay in approval and instability and level of coordination from the project sponsors.

- The fifth most important highway risk factor element is the design risk that is associated with the error in alignment, scope, feasibility studies and traffic flow. 
- The highway risk factor elements in ascending order based on their level of importance are Subcontractor $<$ Site location $<$ Environmental and Geotechnical $<$ Equipment $<$ Economic $<$ Project Finance $<$ Design $<$ Project Sponsor $<$ Project Staff $<$ Construction $<$ Standards and Regulations.

- Application of AHP to risk assessment of five (5) highway construction projects showed the least risky and the most risky highway project and it collaborated with the actual project result when each project was executed.

- The level of risks involved in each project in ascending order as given by the AHP models are: Project $1<$ Project $3<$ Project $5<$ Project $2<$ Project 4.

\section{REFERENCES}

Akadiri, P. O., Olomolaiye, P. O., \& Chinyio, E. A. (2013). Akadiri, P.Multi-criteria evaluation model for the selection of sustainable materials for building projects. . Automat Constr., 113-125.

Akintoye, A. S., \& Macleod, M. J. (1997). Risk analysis and management in construction. International Journal of Project Management, 15(1), 31-38.

Ali, H. H., \& Al Nsairat, S. F. (2009). Developing a green building assessment tool for developing countries-case of Jordan. Build Environ., 44(5), 1053-1064.

Chan, A. P., Yung, E. H., Lam, P. T., Tam, C. M., \& Cheung, S. O. (2001). Chan, A. P., Yung, E. H., Lam, P. T., Application of Delphi method in selection of procurement systems for construction projects. . Constr Manage Econ., 699-718.

Damjan, M., Flevy, L., Matjaz, M., \& Bostjan, G. (2016). Analytic Hierarchy Process Application in Different Organisational Settings, Applications and Theory of Analytic Hierarchy Process - Decision Making for Strategic Decisions. IntechOpen, 100-110.

Hsueh, S. L., Perng, Y. H., Yan, M. R., \& Lee, J. R. (2007). On-line multicriterion risk assessment model for construction joint ventures in China. Automat Constr., 16(5), 607619.

Ishizaka, A., \& Labib, A. (2011b). Review of the main developments in the analytic hierarchy process. Expert Systems with Applications, 38(11), 14336-14345.

ISO. (2009). Risk Management_Principles and Guidelines, Provides Principles, Framework and a Process for Managing Risk. . Switzerland: ISO 31000

Khazandi, G., Khanzandi, M., \& Afshar, A. (2012). Fuzzy adaptive decision making model for selection balanced risk allocation. Int J Proj Manage., 30(4), 511-522.

Lai, J. H., \& Yik, F. W. (2009). Perception of importance and performance of the indoor environmental quality of high-rise residential buildings. Build Environ, 44(2), 352-360.

Nagalla. (2018). Analysis of risk assessment in construction of highway projects using relative important index method. International Journal of Mechanical Engineering and Technology(IJMET), 9(3), 400-410

Nassar, N., \& AbouRizk, S. (2014). Practical application for integrated performance measurement of construction projects. J Manage Eng., 30(6), 1943-5479.

Project Management Institute (PMI), (2000). A Guide to Project Management Body of Knowledge. PA, USA: Upper Darby. 
Ruiz, M. C., Romero, E., Perez, M. A., \& Fernandez, I. (2012). Development and application of a multi-criteria spatial decision support system for planning sustainable industrial areas in Northern Spain. . Automat Constr., 320-333.

Saaty, T. L. (2005). Theory and Applications of the Analytical Network Process: DecisionMaking with Benefits, Opportunities, Costs, and Risk. Pittsburg: RWS Publications.

Wang, M., \& Chou, H. (2003). Risk allocation and risk handling of highway projects in Taiwan. J Manage Eng, 60-80.

Yu, \& Lai, K. K. (2011). A distance-based group decision making methodology for multiperson multi-criteria emergency decision support. Decision Support Systems, 51(2), 307-315. 